\title{
Demonstration of Cross-Reactive Antibodies to Smooth Gram-Negative Bacteria in Antiserum to Escherichia coli J5
}

\author{
J. D. Baumgartner, T. X. O'Brien, T. N. Kirkland, \\ M. P. Glauser, and E. J. Ziegler
}

\author{
From the Division of Infectious Diseases, University of \\ California, San Diego, California; and the Division of \\ Infectious Diseases, Department of Medicine, \\ University Hospital, Lausanne, Switzerland
}

\begin{abstract}
We investigated the discrepancy between the broad cross-protection against gram-negative infections afforded by antiserum to Escherichia coli $\mathbf{J} 5$ and its apparently narrow crossreactivity in vitro. Rabbits immunized with $\mathrm{J} 5$ bacteria produced antibodies to both the J5 lipopolysaccharide (LPS; titer by ELISA, 1:60,000) and LPS from the Re mutant of Salmonella minnesota (i.e., to the ketodeoxyoctonate [KDO] and lipid A determinants; titer, 1:3,200). In highly diluted antiserum, titers of antibody to J5 LPS were reduced by $28 \%-41 \%$ after adsorption with seven strains of smooth gram-negative bacteria and by only $4 \%$ after adsorption with the Re mutant. Smooth gram-negative bacteria adsorbed virtually all antibody to Re LPS. Therefore, rabbit antiserum to J5 contains type-specific antibodies to core determinants distal to KDO that can obscure highly cross-reactive antibodies to lipid A-KDO in vitro. Cross-reactive antibodies are demonstrable by adsorption with whole bacteria at limiting concentrations of antibody.
\end{abstract}

Endotoxins (lipopolysaccharides [LPS]) from rough mutants contain lipid A (the toxic moiety of the molecule) and some sugars from the core region, but, in contrast to LPS from smooth bacteria, they lack the very immunogenic oligosaccharide side chains $[1,2]$. Although these $O$ side chains exhibit wide antigenic variation, the LPS core region is conserved among gram-negative bacteria. Immunizing animals with smooth gram-negative bacteria does not stimulate the formation of cross-protective antibody, despite the fact that LPS from these smooth bacteria also contain the common determinants of core LPS. This observation has been explained by either steric hindrance (because the core LPS is surrounded by side chains) or poor immunogenicity of core LPS compared with the immunogenic dominance of side chains.

Immunization with LPS from rough mutants stimulates high titers of antibody to determinants of LPS core, and the potential of such antisera to protect against a wide variety of unrelated, smooth gram-negative bacteria or endotoxins (LPS) has been established in numerous experimental models [3-13].

Received for publication 3 July 1986, and in revised form 9 February 1987.

This study was supported by grant AI-10108 from the National Institute of Allergy and Infectious Diseases.

Please address requests for reprints to Dr. J. D. Baumgartner, Division of Infectious Diseases, Department of Internal Medicine, CHUV, CH-1011 Lausanne, Switzerland.
Clinical studies have shown that antiserum to Escherichia coli $\mathrm{J} 5$ increased the survival of patients who had gram-negative bacteremia [14] and prevented shock due to gram-negative infections in high-risk surgical patients [15].

Antisera raised to rough mutants have crossprotective activity that we and others have attributed to the presence of antibodies to core LPS $[1,11,16]$, but cross-reaction between antibody to rough mutants and smooth gram-negative bacteria has been difficult to demonstrate in vitro. Immunofluorescent tests using whole smooth bacteria as antigens suggested the existence of cross-reactive antibodies because adsorption of antiserum to the Re mutant of Salmonella minnesota with Re LPS eliminated staining $[17,18]$. However, other attempts in which purified LPS was used as the antigen in direct or indirect HA tests, complement-dependent hemolysis assays, precipitin tests in agar gel, RIAs, ELISAs, and immunoblot assays have revealed little cross-reactive antibody in antisera to rough mutants [19-23 and unpublished observations from the laboratory of E. J. Z. and the late Dr. A. I. Braude.] The discrepancy between the cross-protection observed in animal models and humans and the poor in vitro cross-reactivity of antisera has prompted many to question whether antibody is the protective factor in antiserum to J5. In this paper we show that antibody cross-reactive with smooth gram-negative bacteria can be demonstrated by a sensitive ELISA. 


\section{Materials and Methods}

Bacteria. All bacteria were standard strains from our laboratory, except for the R mutants of S. minnesota (gifts from Dr. O. Lüderitz, Max Planck Institut für Immunobiologie, Freiburg, FRG). The isolates were stored on trypticase soy agar (TSB; Difco, Detroit). For the adsorption experiments, the bacteria were grown overnight at $37 \mathrm{C}$ in TSB, harvested by centrifugation, washed three times in $0.15 M$ $\mathrm{NaCl}$, and boiled for $2.5 \mathrm{hr}$.

LPS. LPS was extracted from rough mutants of $S$. minnesota $\mathrm{Re} 595$ or $E$. coli $\mathrm{J} 5$ by using the phenolchloroform-petroleum ether method of Galanos et al. [24] and from smooth strains (clinical isolates) by the phenol-water method of Westphal et al. [25].

Antisera. Boiled bacterial cells were suspended in $0.15 \mathrm{M} \mathrm{NaCl}$ and adjusted spectrophotometrically to a concentration of $10^{\circ}$ cells $/ \mathrm{ml}(22 \%$ light transmission at $610 \mathrm{~nm}$ ). New Zealand white rabbits weighing $1.5-2.0 \mathrm{~kg}$ were immunized with six iv injections of $1 \mathrm{ml}$ of boiled cells administered during a two-week period. Samples of blood were collected seven days after the last injection and were allowed to clot. The serum was separated by centrifugation, pooled, and stored aseptically at $4 \mathrm{C}$. Each sample of antiserum was a pool from at least two immunized rabbits.

ELISA. We used 96-well, polyvinyl tissue culture plates (Costar, Cambridge, Mass). The peripheral wells were not used because we had previously detected consistent artifacts in reactions in them. Between each step, the wells were washed three times (five times for the last step) with PBS (pH 7.2). PolyL-lysine $\left(\mathrm{M}_{\mathrm{r}}, 90,000\right.$; Sigma, St. Louis) was diluted to $10 \mu \mathrm{g} / \mathrm{ml}$ in PBS, and $50 \mu \mathrm{l}$ was added to each well and allowed to incubate for $30 \mathrm{~min}$ at room temperature. This procedure improved the adherence of LPS to the plastic wells and decreased the background OD (D. Morrison, personal communication). After washing the wells, we added $100 \mu$ of LPS (diluted to $8 \mu \mathrm{g} / \mathrm{ml}$ in PBS) and incubated them overnight at $4 \mathrm{C}$. After another washing, the wells were filled with $150 \mu 1$ of $10 \%$ horse serum in PBS (horse serum buffer). The wells were washed after incubation for $1 \mathrm{hr}$, and $100-\mu \mathrm{l}$ aliquots of rabbit serum diluted in horse serum buffer were added in quadruplicate to the wells. The wells were washed after incubating for $1 \mathrm{hr}$ at $37 \mathrm{C}$, and $100 \mu \mathrm{l}$ of horseradish peroxidase-conjugated goat antibody to rabbit immunoglobulins (Sigma), diluted 1:1,000 in horse se- rum buffer, was added to each well and incubated for $1 \mathrm{hr}$ at $37 \mathrm{C}$. Peroxidase substrate buffer $(90 \mathrm{ml}$ of $\mathrm{H}_{2} \mathrm{O}, 5 \mathrm{ml}$ of $1.0 \mathrm{M}$ citric acid, $5 \mathrm{ml}$ of $1.0 \mathrm{M}$ sodium citrate, $0.33 \mathrm{ml}$ of $3 \% \mathrm{H}_{2} \mathrm{O}_{2}$, and $50 \mathrm{ml}$ of $o$ phenylenediamine [Sigma]) was prepared immediately before use, and $150 \mu \mathrm{l}$ was added to each well. The reaction was stopped after $1 \mathrm{hr}$ at room temperature by adding $40 \mu \mathrm{l}$ of $4 \mathrm{~N} \mathrm{H}_{2} \mathrm{SO}_{4}$ /well. The OD was read at $490 \mathrm{~nm}$ by using a photometer (Dynatech, Chantilly, Va). The titer was defined as the highest dilution yielding an OD of 0.15 .

Adsorption of antisera. Twofold serial dilutions of rabbit antisera were tested by ELISA to determine the titration curve for each antibody. The dilution yielding an OD at the middle part of the sigmoidal titration curve was used for the adsorption experiments. All aliquots (for adsorptions and for controls) were taken from the same batch of antisera diluted in horse serum broth. For adsorptions with bacteria, $1.0 \mathrm{ml}$ of sera diluted in horse serum broth was added to $50-100 \mu \mathrm{l}$ of centrifuged bacteria, mixed, and incubated overnight at $4 \mathrm{C}$. For adsorption with purified LPS, $200 \mu \mathrm{l}$ of a $1 \mathrm{mg} / \mathrm{ml}$ solution of LPS was added to $1.0 \mathrm{ml}$ of diluted sera. The same volume of horse serum broth was added for the control. We used $200 \mu \mathrm{l}$ of either washed, packed human type O erythrocytes or Sephadex ${ }^{\circledast 10}$ (Pharmacia, Piscataway, NJ) as controls for nonspecific adsorption by particles. The sera were then recovered by centrifugation, and the titers of remaining antibody were measured by ELISA. All adsorptions in each experiment were performed the same day.

Statistics. We used analysis of variance (ANOVA) to test the differences between the mean ODs of the experimental groups. When the null hypothesis was rejected by ANOVA, we used the Tukey test for multiple comparison to determine which differences were significant [26].

\section{Results}

Titers of antibody in antisera to LPS from rough bacteria. Table 1 shows the titers of antibody to LPS in antisera from rabbits immunized with various bacteria. Immunizing rabbits with $E$. coli 0111 did not elicit antibodies to LPS from rough bacteria, with the exception of a modest antibody response to the Re core. As expected, the titers of antibody were highest against the homologous LPS from rough bacteria. The only exception was that the titers of antibody to Re LPS were higher in antisera from 
Table 1. Titers of antibody to LPS in antisera from rabbits immunized with various bacteria.

\begin{tabular}{lrrrrr}
\hline & \multicolumn{3}{c}{ Reciprocal titers of antibody to } \\
\cline { 2 - 6 } $\begin{array}{l}\text { Organism used } \\
\text { for vaccination }\end{array}$ & J5 LPS & Ra LPS & Rc LPS & Re LPS & O111 LPS \\
\hline Control (saline) & $<100$ & 200 & $<100$ & 200 & $<100$ \\
E. coli 0111 & $<100$ & $<100$ & $<100$ & 400 & 25,600 \\
J5 mutant* & 60,000 & 200 & 3,200 & 3,200 & 1,600 \\
$S$. minnesota & & & & 3,200 & 200 \\
Ra mutant & 400 & 10,000 & 1,600 & 200 & 800 \\
Re mutant & 400 & 400 & 3,200 & 200 & 100 \\
Re mutant & 200 & 200 & & \\
\hline
\end{tabular}

NOTE. The titer was defined as the highest dilution yielding an OD of 0.15 .

* The J5 mutant of $E$. coli $O 111$ is the equivalent of the Rc mutant of $S$. minnesota.

rabbits immunized with the Ra mutant (antiserum to $\mathrm{Ra}$ ) and the J5 mutant (antiserum to J5) than in antiserum of rabbits immunized with the Re mutant itself (antiserum to $R e$ ), perhaps because of the relatively low immunogenicity of the Re mutant. There were widely different antibody responses between antisera to various rough mutants. Antiserum to J5 behaved differently from antiserum to Rc. Whereas antisera to $\mathrm{J} 5$ and to $\mathrm{Rc}$ had similar titers of antibody to Rc LPS $(1: 3,200)$, antiserum to $\operatorname{Rc}$ had a much lower titer of antibody to J5 LPS $(1: 400)$ than did antiserum to J5 $(1: 60,000)$, a result suggesting that J5 LPS might possess antigenic determinants that are not present on Rc LPS. In fact, $N$-acetylglucosamine has been found in the distal $\mathrm{J} 5$ core and not in the Rc core [1, 2]. These (and other) chemical differences in the composition of the core sugar or lipid A might explain the variety of antibody re- sponses. It is thus clear that the most easily detectable antibodies in antisera to LPS from rough mutants are type-specific.

Adsorption of antiserum to J5 with purified LPS. In two experiments, adsorption of antiserum to J5 (diluted 1:10,000) with LPS from smooth bacteria produced only a small decrease in titer of antibody to J5 LPS (table 2). To find out if antibody to core LPS in antiserum to J5 bound to LPS from smooth bacteria, we measured in vitro antibody binding to LPS from smooth bacteria before and after adsorption with J5 LPS.

Much to our surprise, after adsorption with J5 LPS, there was a several-fold increase in titer of antibody to LPS from smooth bacteria (table 3). This result raises the possibility that J5 LPS-antibody complexes remained in the antisera despite the centrifugation step and were subsequently adsorbed

Table 2. Antibodies to J5 LPS in rabbit antiserum to $E$. coli J5: adsorption with purified LPS.

\begin{tabular}{|c|c|c|c|c|}
\hline \multirow[b]{3}{*}{$\begin{array}{l}\text { LPS used } \\
\text { for adsorption }\end{array}$} & \multicolumn{4}{|c|}{ Antibodies to J5 LPS } \\
\hline & \multicolumn{2}{|c|}{ First experiment } & \multicolumn{2}{|c|}{ Second experiment } \\
\hline & $\mathrm{OD}(\mathrm{SD})$ & $\begin{array}{l}\text { Decrease in OD }(\%) \\
\text { after adsorption }\end{array}$ & OD (SD) & $\begin{array}{c}\text { Decrease in } \mathrm{OD}(\%) \\
\text { after adsorption }\end{array}$ \\
\hline No adsorption* & $0.724(0.021)$ & - & $0.591(0.032)$ & - \\
\hline Klebsiella pneumoniae & $0.681(0.042)$ & 6 & $0.513(0.025)$ & 14 \\
\hline E. coli $\mathrm{O} 4$ & $0.658(0.003)$ & 9 & $0.470(0.014)$ & 21 \\
\hline Salmonella typhimurium & $0.647(0.20)$ & 11 & $0.544(0.027)$ & 8 \\
\hline E. coli 0113 & $0.635(0.001)$ & 12 & $0.503(0.029)$ & 15 \\
\hline Serratia marcescens & $0.620(0.001)$ & 14 & $0.543(0.028)$ & 8 \\
\hline E. coli 0111 & $0.584(0.013)$ & 19 & $0.517(0.019)$ & 13 \\
\hline Rough mutant of $E$. coli $0113^{\dagger}$ & $0.209(0.008)$ & 71 & $0.138(0.005)$ & 77 \\
\hline E. coli $\mathrm{J5}$ & $0.107(0.003)$ & 85 & $0.066(0.004)$ & 89 \\
\hline
\end{tabular}

NOTE. The OD values are the mean of four readings; the background values (from wells with nonimmune serum) have already been subtracted (mean OD [SD], $0.02[0.002]$ ). The dilution of antiserum to J5 was 1:10,000.

* A volume of horse serum buffer similar to that of soluble LPS was added to the serum.

$\dagger$ Rc-type mutant of E. coli O113. 
Table 3. Antibodies to Ra LPS, E. coli O4 LPS, and Pseudomonas aeruginosa LPS in rabbit antiserum to $E$. coli J5: adsorption with various antigens.

\begin{tabular}{lccc}
\hline & \multicolumn{2}{c}{$\begin{array}{c}\text { Titer of indicated antibody in } \\
\text { antiserum to J5 }\end{array}$} \\
\cline { 2 - 3 } $\begin{array}{l}\text { Antigens used } \\
\text { for adsorption }\end{array}$ & $\begin{array}{c}\text { Antibody to } \\
\text { Ra LPS }\end{array}$ & $\begin{array}{c}\text { Antibody } \\
\text { to } E \text {. coli } \\
\text { O4 LPS }\end{array}$ & $\begin{array}{c}\text { Antibody to } \\
\text { P. aeruginosa } \\
\text { LPS }\end{array}$ \\
\cline { 1 - 1 } B. subtilis & $0.22^{*}$ & 0.20 & 0.16 \\
$\begin{array}{l}\text { E. coli J5 } \\
\text { J5 LPS }\end{array}$ & 0.22 & 0.15 & 0.16 \\
Homologous & 1.89 & 0.59 & 1.32 \\
$\quad$ & & & \\
bacteria & 0.18 & 0.10 & 0.11 \\
Homologous LPS & 0.22 & 0.07 & 0.13 \\
\hline
\end{tabular}

NOTE. The dilution of antiserum to $\mathrm{J} 5$ was 1:20.

* Mean of 2 OD values.

onto the ELISA plates. This artifact is an interesting phenomenon with general application, and it should be investigated further. Because we did not observe it when whole $\mathrm{J} 5$ bacteria were used instead of purified LPS (table 3), we decided to perform all further adsorption experiments with whole bacteria instead of LPS.

Adsorption of antisera to J5 and Re with whole bacterial cells. Preliminary experiments (table 4) demonstrated that adsorption of antiserum to $\mathrm{J} 5$, diluted 1:400 with $E$. coli O111 (the smooth parent of the J5 mutant), did not perceptibly lower the titer
Table 4. Effect of dilution on antibody to J5 LPS in rabbit antiserum to $E$. coli $\mathrm{J} 5$

\begin{tabular}{lcc} 
& \multicolumn{1}{c}{$\begin{array}{c}\text { OD of antibody to } \mathrm{J} 5 \text { in } \\
\text { antiserum to } \mathrm{J} 5\end{array}$} \\
\cline { 2 - 3 } $\begin{array}{l}\text { Bacteria used } \\
\text { for adsorption }\end{array}$ & $\begin{array}{c}\text { Experiment } 1 \\
(1: 400 \text { dilution })\end{array}$ & $\begin{array}{c}\text { Experiment 2 } \\
(1: 6,400 \text { dilution })\end{array}$ \\
\hline None & $>1.55$ & $>1.55$ \\
E. coli O111 & $>1.55$ & 1.48 \\
E. coli $\mathrm{J} 5$ & 0.15 & 0.037 \\
\hline
\end{tabular}

of antibody to J5 LPS, whereas adsorption with the homologous $\mathrm{J} 5$ mutant did. Adsorption of antiserum to J5 (diluted 1:6,400) with $E$. coli O111 decreased the titer of antibody to J5 LPS only slightly. From these results we concluded that it was necessary to use highly diluted antiserum to demonstrate that adsorption with smooth gram-negative bacteria decreased the titer of antibody to J5 LPS. Therefore, we used dilutions of antisera yielding one-half of the maximal $O D$ values.

When J5 LPS was used as an antigen on ELISA plates, adsorption of antiserum to J5 (diluted 1:10,000) with smooth gram-negative bacteria significantly lowered (by 28\%-41\%) the OD values, compared with those of unadsorbed controls or serum adsorbed with gram-positive Bacillus subtilis $(P<.001$; table 5$)$. Adsorption by the Rc mutant

Table 5. Antibodies to J5 LPS and Re LPS in rabbit antiserum to E. coli J5: adsorption with various bacteria.

\begin{tabular}{|c|c|c|c|c|}
\hline \multirow[b]{3}{*}{$\begin{array}{l}\text { Bacteria used } \\
\text { for adsorption }\end{array}$} & \multicolumn{4}{|c|}{ Level of indicated antibody in antiserum to $\mathrm{J} 5$} \\
\hline & \multicolumn{2}{|c|}{ Antibody to J5 LPS } & \multicolumn{2}{|c|}{ Antibody to $\operatorname{Re}$ LPS } \\
\hline & OD (SD) & $\begin{array}{c}\text { Decrease in OD (\%) } \\
\text { after adsorption }\end{array}$ & $\mathrm{OD}(\mathrm{SD})$ & $\begin{array}{c}\text { Decrease in OD (\%) } \\
\text { after adsorption }\end{array}$ \\
\hline No adsorption & $0.99(0.028)$ & - & $0.88(0.037)$ & - \\
\hline B. subtilis & $0.98(0.043)$ & 1 & $0.53(0.043)$ & 39 \\
\hline Re mutant & $0.95(0.076)$ & 4 & $0.09(0.021)$ & 90 \\
\hline S. minnesota & $0.71(0.029)$ & 28 & $0.02(0.025)$ & 98 \\
\hline P. aeruginosa & $0.69(0.026)$ & 30 & $0.01(0.031)$ & 99 \\
\hline S. marcescens & $0.68(0.036)$ & 31 & $0.06(0.006)$ & 93 \\
\hline$K$. pneumoniae & $0.65(0.009)$ & 34 & $0.11(0.018)$ & 88 \\
\hline Ra mutant & $0.63(0.008)$ & 36 & $0.11(0.031)$ & 88 \\
\hline E. coli 0111 & $0.63(0.039)$ & 36 & $0.05(0.006)$ & 94 \\
\hline E. coli $\mathrm{O} 17$ & $0.58(0.027)$ & 41 & $0.08(0.018)$ & 91 \\
\hline Rc mutant & $0.50(0.044)$ & 49 & $0.10(0.049)$ & 89 \\
\hline $\mathrm{J} 5$ mutant & $0.03(0.003)$ & 97 & $0.26(0.012)$ & 70 \\
\hline
\end{tabular}

NOTE. The antiserum to J5 was diluted 1:10,000 to measure antibody to J5 LPS and 1:400 to measure antibody to Re LPS.

* The OD values are the mean of four values. The mean OD values for unadsorbed sera were standardized to 1.00 , and then the background OD was subtracted; the same standardization was applied to the other OD values. (The mean background OD [SD] was 0.01 [0.003] for the plates with J5 LPS and 0.12 [0.018] for the plates with Re LPS.) 
decreased the OD value by $49 \%$, a value significantly less than the $97 \%$ adsorption by the J5 mutant $(P<.001)$; this result also suggests that J5 LPS must have antigenic determinants not available on Rc LPS. There was essentially no decrease in antibody binding after adsorption by the Re mutant, whose LPS contains only lipid A and ketodeoxyoctonate (KDO), a result suggesting that antibodies to the lipid A-KDO region represent only a minor fraction of the overall antibodies to J5 LPS in rabbit antiserum to J5. Therefore, it can be deduced that the antibodies to J5 LPS that were removed by incubation with unrelated, smooth gram-negative bacteria were directed against distal determinants of the core sugar rather than against the lipid A-KDO region.

When Re LPS was used as the coating antigen, the titer of antibody in antiserum to J5 $(1: 3,200)$ was much lower than the titer of antibody to J5 LPS $(1: 60,000 ;$ table 1$)$. Therefore, we used serum diluted 1:400 for the adsorption experiments. Adsorption with smooth gram-negative bacteria was as effective as adsorption with rough mutants (table 5). This observation is strong evidence of the cross-reactive nature of these antibodies to the lipid A-KDO region. Adsorption by $B$. subtilis produced a decrease of $39 \%$ in the OD value. We also observed a similar decrease in OD after adsorption with other gram-positive bacteria such as Streptococcus faecalis and Staphylococcus epidermidis ( $53 \%$ and $39 \%$ decrease, respectively) and with Candida albicans ( $21 \%$ decrease). This result might have been due to nonspecific adsorption by the gram-positive bacteria. However, nonspecific adsorption seems an unlikely explanation because adsorption with two nonspecific particulate controls (washed, packed erythrocytes and Sephadex G10) had absolutely no effect on the titers of antibody to J5 LPS or to Re LPS in antiserum to J5 or on titers of antibody to $R e$ in antiserum to $\operatorname{Re}$ (data not shown). It is more likely that the decreased titers of antibody after adsorption with gram-positive bacteria were due to the presence of determinants on the cell wall of gram-positive bacteria; such determinants would cross-react with antibodies to lipid A-KDO. These results with gram-positive bacteria were significantly lower than those obtained after adsorption with smooth gram-negative bacteria $(P<.05)$.

To find out if antibodies to the lipid A-KDO region in antiserum to Re behaved similarly, we subjected antiserum to Re to the same battery of adsorptions (table 6). The working dilution of antiserum to $\operatorname{Re}$ was also 1:400. The gram-positive
Table 6. Antibody to Re LPS in rabbit antiserum to $E$. coli J5: adsorption with various bacteria.

\begin{tabular}{lcc}
\hline & \multicolumn{2}{c}{ Antibody to Re LPS } \\
\cline { 2 - 3 } $\begin{array}{l}\text { Bacteria used } \\
\text { for adsorption }\end{array}$ & OD* (SD) & $\begin{array}{c}\text { Decrease in OD (\%) } \\
\text { after adsorption }\end{array}$ \\
\hline No adsorption & $0.23(0.018)$ & - \\
B. subtilis & $0.18(0.028)$ & 22 \\
E. coli O17 & $0.08(0.020)$ & 65 \\
E. coli O111 & $0.06(0.016)$ & 74 \\
J5 mutant & $0.06(0.029)$ & 74 \\
$K$. pneumoniae & $0.05(0.012)$ & 78 \\
$S$. marcescens & $0.04(0.009)$ & 83 \\
Ra mutant & $0.04(0.009)$ & 83 \\
Rc mutant & $0.02(0.019)$ & 91 \\
$S$. minnesota & $0.01(0.002)$ & 96 \\
$P$. aeruginosa & $0.01(0.010)$ & 96 \\
Re mutant & $0.00(0.008)$ & 100 \\
\hline
\end{tabular}

NOTE. The antiserum to $\mathrm{Re}$ was diluted 1:400.

* Mean of four values after subtraction of the background (mean OD [SD], 0.06 [0.013]).

organisms also adsorbed antibodies slightly (decrease of $10 \%-30 \%$ of OD values). Smooth gram-negative bacteria, however, removed most of the antibody to Re LPS from the antiserum $(66 \%-93 \%, P<.05$ compared with the results of adsorptions with grampositive organisms). Therefore, in another system, antibodies to lipid A-KDO are cross-reactive with smooth gram-negative bacteria.

\section{Discussion}

We and others have contended that the mechanism of protection afforded by antiserum to J5 or plasma to J5 in preventing septic shock involves neutralization of the harmful effects of endotoxins by means of cross-reactive antibodies to the determinants of core LPS. Three different lines of argument favor this hypothesis. First, retrospective studies in humans have reported a significant correlation between titers of antibody to core LPS and survival of patients with gram-negative bacteremia due to many different organisms $[27,28]$. This correlation was independent of the titers of strain-specific antibodies and suggested therefore that antibody to core LPS can protect patients from severe septic shock or death due to gram-negative bacteria. Second, in a controlled, prospective clinical study, plasma to J5 prevented septic shock and death due to gram-negative, but not gram-positive, organisms [15]; therefore, the crossprotection was specific for gram-negative bacteria. 
Third, the hypothesis of protective antibody to core LPS is supported by previous animal experiments showing cross-protection from antiserum to $\mathrm{J} 5$ not only against whole gram-negative bacteria, but also against purified endotoxins [3-13]. This suggests that if a cross-reactive antibody is involved in the protection afforded by antiserum to $\mathrm{J} 5$, it is probably directed against determinants of LPS and not against other cell wall determinants on the gramnegative bacteria. Because common LPS epitopes are found only in the core portion of LPS, it seems reasonable to postulate that cross-protective antibodies are directed against these determinants. Some investigators have suggested that cross-protection is due to activation of polyclonal $B$ cells by rough LPS with accompanying production of antibodies. Although we cannot exclude this possibility altogether, immunization with smooth gram-negative bacteria (which also are polyclonal stimulators) does not result in cross-protective antiserum [3-13]; therefore, polyclonal activation is unlikely to explain protection.

The idea that cross-protection is due to antibody to core LPS has been questioned because crossreaction with LPS from smooth bacteria or with gram-negative bacteria has been extremely difficult for us and some others to demonstrate in vitro [17-23]. Moreover, in two successful clinical trials that clearly showed the effectiveness of administering antiserum to $\mathrm{J} 5$ or plasma to $\mathrm{J} 5$, the relation between the amount of measured antibody to J5 LPS given to the patients and an improved outcome was not strong $[14,15]$.

In the present study, we have addressed these discrepancies. We have found wide variations in titers of antibody to $\mathrm{Ra}, \mathrm{Rc}, \mathrm{Re}$, and J5 LPS (as measured by ELISA) after immunizing rabbits with these rough mutants. Therefore, the rough mutants seem to vary considerably in their immunogenicity. Furthermore, we have found that the majority of these antibodies are type-specific for the LPS from the immunizing rough mutant. A similar conclusion has also been drawn from experiments using IHA to measure antibody to LPS from rough bacteria [29]. To improve the detection of cross-reactive antibodies in polyclonal antisera, we have used several techniques. Adsorption with whole bacteria detects binding to LPS in its most natural conformation. Furthermore, when detecting antibodies of different binding specificities that are present in widely varying concentrations, different dilutions of antibodies are required. For ex- ample, antibodies to J5 LPS are detectable at dilutions as high as $1: 60,000$. In the same serum, antibodies to Re LPS are detectable at 1:3,200. When we used dilutions that yielded one-half of the maximum OD values, adsorption of the antibody to J5 LPS with various smooth gram-negative bacteria revealed a definite but modest amount of crossreactivity. On the other hand, adsorption of antibody to Re LPS in the same serum revealed very strong cross-reactions. Although we cannot prove that adsorption by gram-positive bacteria was specific, the fact that this phenomenon was not observed with nonspecific adsorbents or in the highly diluted antiserum assayed against J5 LPS suggests that this reaction was specific. Therefore, we suspect that antibodies to Re LPS cross-react with some cell wall determinants (such as glucosamine epitopes) that are shared by peptidoglycan in gram-positive organisms and by LPS core in gram-negative organisms.

In a recent study, Siber et al. [22] were not able to demonstrate cross-reactive antibody to core LPS in antisera of rabbits immunized with LPS from rough mutants. These authors used ELISA tests and adsorption experiments with soluble LPS, LPS linked to outer membrane vesicles, and whole, gramnegative bacteria. Their results might be explained by the fact that they used antisera diluted only 1:25. At this dilution, ELISAs using the whole molecule of LPS from J5 as a coating antigen detect mainly strain-specific antibodies in polyclonal antiserum to J5. The recent immunoblotting study by de JonghLeuvenink et al. [23] used undiluted antiserum to J5 for adsorption. They found some evidence of cross-reactivity with core LPS from $E$. coli and from $S$. typhimurium Re, but none with core LPS from smooth gram-negative strains. The same technical problem may also explain the difficulty in correlating clinical outcome with titers of antibody to J5 LPS in our own clinical trials $[14,15]$.

The finding that antiserum to JS contains highly cross-reactive antibody to Re LPS is consistent with results we and others have obtained by using monoclonal antibodies. Several groups have reported highly cross-reactive monoclonal antibodies specific for the lipid A-KDO region of the LPS molecule [30-33]. Others have reported that antibodies to the core polysaccharide distal to KDO are poorly crossreactive $[34,35$, and authors' unpublished observations].

Polyclonal antisera to J5 LPS from the rough mutant clearly contain considerable amounts (detect- 
able at a dilution of $1: 10,000$ ) of antibody that is cross-reactive with smooth gram-negative bacteria. In vitro assays such as ELISAs are highly influenced by antibody-binding characteristics. Differences in antibody-binding characteristics between typespecific and cross-reactive antibodies to J5 LPS may account for the difficulties in demonstrating crossreactivity with smooth gram-negative bacteria in antiserum to J5. Adsorption studies done at limiting concentrations of antibody are more sensitive in detecting cross-reactive binding than are adsorption experiments performed with an excess of antibody. We speculate that our assay requires limiting concentrations of antibody to detect cross-reactive, but not type-specific, antibody because the avidity of the antibody binding to smooth gram-negative bacteria is lower than the avidity of the antibody binding to J5 bacteria. The mechanistic implications of such binding are beyond the scope of this paper. We merely wish to present a way in which cross-reactive antibodies to smooth bacteria can be demonstrated easily and consistently in polyclonal antisera to LPS from rough mutants.

\section{References}

1. Jansson P-E, Lindberg AA, Lindberg B, Wollin R. Structural studies on the hexose region of the core in lipopolysaccharides from enterobacteriaceae. Eur J Biochem 1981; 115:571-7

2. Westphal O, Jann K, Himmelspach K. Chemistry and immunochemistry of bacterial lipopolysaccharides as cell wall antigens and endotoxins. Prog Allergy 1983;33:9-39

3. McCabe WR. Immunization with R mutants of $S$. minnesota. I. Protection against challenge with heterologous gramnegative bacilli. J Immunol 1972;108:601-10

4. Ziegler EJ, Douglas H, Sherman JE, Davis CE, Braude AI. Treatment of $E$. coli and Klebsiella bacteremia in agranulocytic animals with antiserum to a UDP-Gal epimerasedeficient mutant. J Immunol 1973;111:433-8

5. Ziegler EJ, McCutchan JA, Douglas H, Braude AI. Prevention of lethal pseudomonas bacteremia with epimerasedeficient $E$. coli antiserum. Trans Assoc Am Phys 1975; 88:101-8

6. Bruins SC, Stumacher R, Johns MA, McCabe WR. Immunization with $\mathrm{R}$ mutants of Salmonella minnesota. III. Comparison of the protective effect of immunization with lipid $A$ and the Re mutant. Infect Immun 1977;77:16-20

7. Johns M, Skehill A, McCabe WR. Immunization with rough mutants of Salmonella minnesota. IV. Protection by antisera to $O$ and rough antigens against endotoxin. $J$ Infect Dis 1983;147:57-67

8. Marks MI, Ziegler EJ, Douglas H, Corbeil LB, Braude AI. Induction of immunity against lethal Haemophilus influenzae type b infection by Escherichia coli core lipopolysaccharide. J Clin Invest 1982;69:742-9
9. Ziegler EJ, Douglas H, Braude AI. Human antiserum for prevention of the local Shwartzman reaction and death from bacterial lipopolysaccharides. J Clin Invest 1973; 52:3236-8

10. Braude AI, Douglas H. Passive immunization against the local Shwartzman reaction. J Immunol 1972;108:505-12

11. Braude AI, Douglas H, Davis CE. Treatment and prevention of intravascular coagulation with antiserum to endotoxin. J Infect Dis 1973;128(Suppl):S157-64

12. Davis CE, Ziegler EJ, Arnold KF. Neutralization of meningococcal endotoxin by antibody to core glycolipid. J Exp Med 1978;147:1007-17

13. Young LS, Stevens P, Ingram J. Functional role of antibody against "core" glycolipid of Enterobacteriaceae. J Clin Invest 1975;56:850-61

14. Ziegler EJ, McCutchan JA, Fierer J, Glauser MP, Sadoff JC, Douglas H, Braude AI. Treatment of gram-negative bacteremia and shock with human antiserum to a mutant Escherichia coli. N Engl J Med 1982;307:1225-30

15. Baumgartner J-D, Glauser MP, McCutchan JA, Ziegler EJ, van Melle G, Klauber MR, Vogt M, Muehlen E, Luethy R, Chiolero R, Geroulanos S. Prevention of gram-negative shock and death in surgical patients by antibody to endotoxin core glycolipid. Lancet 1985;2:59-63

16. Braude AI, Ziegler EJ, McCutchan JA, Douglas H. Immunization against nosocomial infection. Am J Med 1981; 70:463-6

17. Young LS, Hoffman KR, Stevens P. "Core" glycolipid of enterobacteriaceae: immunofluorescent detection of antigen and antibody. Proc Soc Exp Biol Med 1975;149:389-96

18. Eskenazy M, Konstantinov G, Ivanova R, Strahilov D. Detection by immunofluorescence of common antigenic determinants in unrelated gram-negative bacteria and their lipopolysaccharides. J Infect Dis 1977;135:965-9

19. Chedid L, Parant M, Parant F, Boyer F. A proposed mechanism for natural immunity to enterobacterial pathogens. J Immunol 1968; 100:292-301

20. Ng A-K, Chen C-LH, Chang C-M, Nowotny A. Relationship of structure to function in bacterial endotoxins: serologically cross-reactive components and their effect on protection of mice against some gram-negative infections. J Gen Microbiol 1976;94:107-16

21. Johns MA, Bruins SC, McCabe WR. Immunization with $R$ mutants of Salmonella minnesota. II. Serological response to lipid $\mathrm{A}$ and the lipopolysaccharide of Re mutants. Infect Immun 1977;17:9-15

22. Siber GR, Kania SA, Warren HS. Cross-reactivity of rabbit antibodies to lipopolysaccharides of Escherichia coli J5 and other gram-negative bacteria. J Infect Dis 1985; 152:954-64

23. de Jongh-Leuvenink J, Vreede RW, Marcelis JH, de Vos M, and Verhoef J. Detection of antibodies against lipopolysaccharides of Escherichia coli and Salmonella $R$ and S strains by immunoblotting. Infect Immun 1985;50:716-20

24. Galanos $C$, Lüderitz $O$, Westphal $O$. A new method for the extraction of $\mathbf{R}$ lipopolysaccharides, Eur $\mathbf{J}$ Biochem 1969;9:245-9

25. Westphal $O$, Lüderitz $O$, Bister F. Über die Extraktion von Bakterien mit Phenol/Wasser. Z Naturforsch Teil B 1952; $7 \mathrm{~b}: 148-55$

26. Zar JH. Multiple comparisons. In: Zar JH, ed. Biostatisti- 
cal analysis. 2nd ed. Englewood Cliffs, NJ: Prentice-Hall, 1984:185-205

27. McCabe WR, Kreger BE, Johns $M$. Type-specific and crossreactive antibodies in gram-negative bacteremia. New Engl J Med 1972;287:261-7

28. Zinner SH, McCabe WR. Effects of IgM and IgG antibody in patients with bacteremia due to gram-negative bacilli. J Infect Dis 1976;133:37-45

29. Pollack M, Huang AI, Prescott RK, Young LS, Hunter KW, Cruess DF, Tsai C-M. Enhanced survival in Pseudomonas aeruginosa septicemia associated with high levels of circulating antibody to Escherichia coli endotoxin core. $\mathrm{J}$ Clin Invest 1983;72:1874-81

30. Nelles MJ, Niswander CA. Mouse monoclonal antibodies reactive with $\mathbf{J} 5$ lipopolysaccharide exhibit extensive serological cross-reactivity with a variety of gram-negative bacteria. Infect Immun 1984;46:677-81

31. Mutharia LM, Crockford G, Bogard WC Jr, Hancock REW.
Monoclonal antibodies specific for Escherichia coli J5 lipopolysaccharide: cross-reaction with other gram-negative bacterial species. Infect Immun 1984;45:631-6

32. Dunn DL, Bogard WC Jr, Cerra FB. Efficacy of type-specific and cross-reactive murine monoclonal antibodies directed against endotoxin during experimental sepsis. Surgery 1985;98:283-8

33. Teng NNH, Kaplan HS, Hebert JM, Moore C, Douglas $H$, Wunderlich A, Braude AI. Protection against gramnegative bacteremia and endotoxemia with human monoclonal IgM antibodies. Proc Natl Acad Sci USA 1985; 82:1790-4

34. Kirkland TN, Ziegler EJ. An immunoprotective monoclonal antibody to lipopolysaccharide. J Immunol 1984; 132:2590-2

35. Gigliotti F, Shenep JL. Failure of monoclonal antibodies to core glycolipid to bind intact smooth strains of Escherichia coli. J Infect Dis 1985;151:1005-11 